横断時の斜路のすべりの考察および安全性からみた斜路のすべりの 総括的評価方法の提示

\title{
CONSIDERING THE SLIPPERINESS OF INCLINED FLOORS IN GOING ACROSS MOVEMENT AND PRESENTATION OF GENERAL EVALUATION METHOD OF SLIPPERINESS OF INCLINED FLOORS FROM A VIEWPOINT OF SAFETY
}

\author{
小野英哲* \\ Hidenori ONO
}

\begin{abstract}
The slipperiness of inclined floors is very important performance item for human from a viewpoint of safety in every movement.

In former report, anthers presented the method to evaluate the slipperiness of inclined floors in going up and down and changing direction.

In this report, anther present the method to evaluate the slipperiness of inclined floors in going across, dealing with the coefficient of slip resistance, C.S.R $\mathrm{Li}$, detected by slip meter named "O - Y • Pull Slip Meter" developed by auther et. al.

Finely, auther present the method to evaluate the slipperiness of various inclined floors generally in every movement such as going up and down, going across, changing direction and in every factors such as sex, age, shoes.
\end{abstract}

Keywords : inclined floors, slipperiness, going across, safety, general evaluation method 斜路、すべり、横断時、安全性、総括的評価方法

1. 序

一般に斜路は高低差のある2点を結ぶ経路のひとうとして設置さ れる。このため、水平な通路と比較して斜路には動作のしやすさ、 安全性の観点から傾斜、すべり、手摺などに関しより慎重な対策が 求められるのは当然といえる。

一方、既往の斜路に関する調查・研究や法律はおもに人の上り、 下り、時の斜路のあり方を対象としており、他の動作時、特に横断 時の安全性に関して検討している例はない。

横断時の足の接触状況、踏力の作用状況および姿勢は、上り、下 りの場合と異なることから、安全性に関する諸事項を別途に検討す る必要があるが、特にすべり抵抗の検討は重要な課題として位置づ けられる。

本研究は横断時の斜路のすべりを検討した後、既往の成果 ${ }^{11}$ 、2) をも含め総括的に、安全性の観点から斜路のすべりを評価する方法 を検討したものである。

\section{2. 目的と範囲}

本研究の目的はまず横断時の斜路のすべりに関し、実情と高い相 関をもって測定できるすべり試験方法ついて検討するとともに、安 全性の観点からの評価指標を求め、つきに、既往の研究成果 ${ }^{11 、 2) ~}$ を合せて、安全性からみた斜路のすべりの総括的評価方法を提示す ることにある。

対象とする斜路は屋内外に設置される斜路全般とするが得られ
る成果は坂道、傾斜のある犬走りなどにも適用できるものである。 また、斜路仕上面の諸性質とすべりの関係の提示、すべりからみ て安全な仕上面の開発などは範囲外とする。なお、評価方法を確立 できれば、より速やかにかつ合理的に安全な仕上面の提示、開発を 行えると考える。

ここで横断に供する斜路の代表例および横断時のすべりを検討 する意義を述べる。

設置時の意図にかかわらず横断に供するのはすべての斜路とい えるか、特に図 1 に例示するような個所に設置される斜路において 横断に供する頻度が高くなることが観察される。

（イ）は、建物の出入口と歩道の間に高低差がある場合に設置さ れる斜路で、建物に添って移動している歩行者が斜路を避けること なく横断する例である。

（ロ）は、車道と駐車スペースの間に歩道がある場合、車を出入 させるために歩道に設置される斜路で、歩道に添って移動している 歩行者が必然的に横断する例である。

他にもいくつかのタイブがあるが、いずれにせよこれらの斜路が 建物内外に数多く存在するのは事実である。

さらに統計量としては把握できないが、特に屋外や玄関ホールに 斜路が設置される場合、雨水などですべりやすくなるため横断時の 側方転倒事故などが多いことを見聞きする。

以上より、横断時のすべりを検討することは、斜路のすべりを総 括的に検討する上で必要不可欠な課題といえる。 


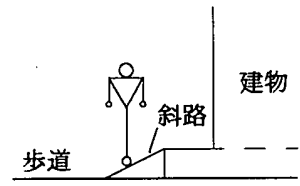

(1)

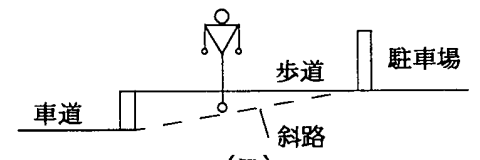

(ㅁ)
図 1 横断に供する斜路の例

\section{3. 既往の研究}

斜路のすべりに関する調查・研究は少ないか、おもな例としては 以下が挙げられる。

宇野らは斜路の傾斜を、林のすべりに影響を及ぼす要因のひとつ として考察している゙う。坂田らは斜路を上り、下方する時の必要摩 擦䋆数について考察している ${ }^{4)}$ 。独国障害保険協会は、DIN 51097 に基づき水迴りに用いられる傾斜した床のセラミック系床仕上材 料について、素足が濡れた状態で歩行する際に危険と感じる傾斜角 度を求め、適切な使用条件を設定している5)。

しかしこれらは、仕上材料を媒体とした定性的な検討にとどまっ ていること、傾斜角度さらには動作とすべりの関係を究明していな いこと、限定された状況でのすべりを対象としていること、などの 理由から、著者らは新たな観点で斜路のすべりの評価方法を提示し ている1队2)。

なお、著者らは車椅子の走行性からみた斜路のすべりの評価方法 も提示している6)。

いずれも参考にはなるが、横断時のすべりさらには、他の代表的 な動作時のすべりも含めて総括的に斜路のすべりを論した調查・研 究報告はなく今後の課題として位置つけられる。

\section{4. 研究方法の概要}

研究方法の概要はつきのとおりである。

(1)横断時の斜路のすべりの安全性の程度を人の判断を用いて尺 度化し、すべり評価尺度（以降、すべり評価尺度・横断、と呼ふ） として定量的に把握する。

ここで、斜路のすべりの安全性の程度を定量的に求める方法とし ては、例えば斜路における接触時の足の動きを媒体とするなどの方 法も考えられるが、動く、動かないなどの現象からは多くの情報を 得られないことが明確なので、本研究では既往の研究 ${ }^{11}$ ２1 と同様 に動作時の人の判断を媒体として尺度を構成することとする。

(2)すべり評価尺度・横断を表示するすべり抵抗を設定する。

(3)すべり評価尺度・横断とすべり抵抗の対応から、横断時の安 全性からみた斜路のすべりの評価指標を提示する。

(4)既往の研究 ${ }^{11}$ ２) で提示した評価指標を含め、安全性からみた 斜路のすべりの総括的評価指標および評価方法を提示する。

\section{5. 横断時の安全性加らみた斜路のすべりの評価指相の提示}

5. 1.すべり評価尺度・横断の構成

5.1.1すべり評価尺度・横断構成のための検查

唡查の概要を表 1 に示すとともに、おもな事項について説明を加 える。

（1）尺度構成手法

尺度構成手法としては、試料斜路のすべりの安全性を 7 段階の判
断範ちのうを用いて絶対判断する結果から尺度を構成する系列範 ちゅう法 ${ }^{7)}$ を用いることとした。

( 2 ）試料斜路の概要

試料斜路の概要を表 1 、図 2 に示す。

試料斜路は大きく検査員の横断歩行に供する斜路板、斜路板を所 定の傾斜角度に設置する架台からなっている。

傾斜角度は、架台に設けた穴に架構した鋼棒に、斜路板下面に取 り付けた溝治具をはめ込むことにより設定する。ここで傾斜角度 $\theta$ は水平 $\left(0^{\circ}\right)$ を含む 7 段階で、最大角度は仙台市内屋内外の斜路の 傾斜を調查した結果をもとに設定している。なお、建築基準法では、 斜路の最大勾配を車椅子の場合 $1 / 12\left(4.7^{\circ}\right)$ 、人間歩行の場 合 $1 / 8\left(7.1^{\circ}\right)$ と規定しているか、本研究ではこれらの規定に こだわらず、現実に存在する斜路の傾斜角度を包含するように設定 している。

検查に供する試料斜路の仕上面材料の仕様および斜路上下方向 のすべり抵抗 C.S.R は表 1 に示すとおりで、すべる試料からすべら ない試料まで分布するように設定している。

C.S.R は図 3 に示すすべり試験機( 0-Y·PSM )による值で、検查 で使用する履物底前半部を所定の形に切り取り、表面に綿ブロード

（40 番）を貼布したすべり片を用いて求めたものである。

ここで、0-Y·PSM は著者の構想をもとに研究開発し、JIS A 1454 「高分子系張り床材試験方法」にも規定されているすべり試験機で、 履物底前半部を所定の形に切り取ってすべり片とし、水平に設置し た試料に対し、重鍾による鉊直荷重を $80 \mathrm{kgf}(784 \mathrm{~N})$ 、初期引 張荷重を $3 \mathrm{kgf}(29.4 \mathrm{~N})$ 、前置時間を $0 \mathrm{sec}$ 、荷重速度を $80 \mathrm{kgf}$ / $\sec (784 \mathrm{~N} / \mathrm{s})$ として斜め上方 $\left(18^{\circ}\right)$ にすべり片を引張った

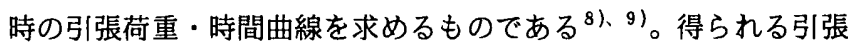
荷重・時間曲線の例は図 4 のとおりで、すべり片がすべり始めると きの最大引張荷重(Pmax)を抽出し、下式によりすべり抵抗 C.S.R (Coefficient of Slip Resistance) を求めるものである。

C.S.R = Pmax $\operatorname{kgf}(\mathrm{N}) / 80 \mathrm{kgf}(784 \mathrm{~N})$

表 1 斜路横断時のすべりの安全性に関する検查の概要

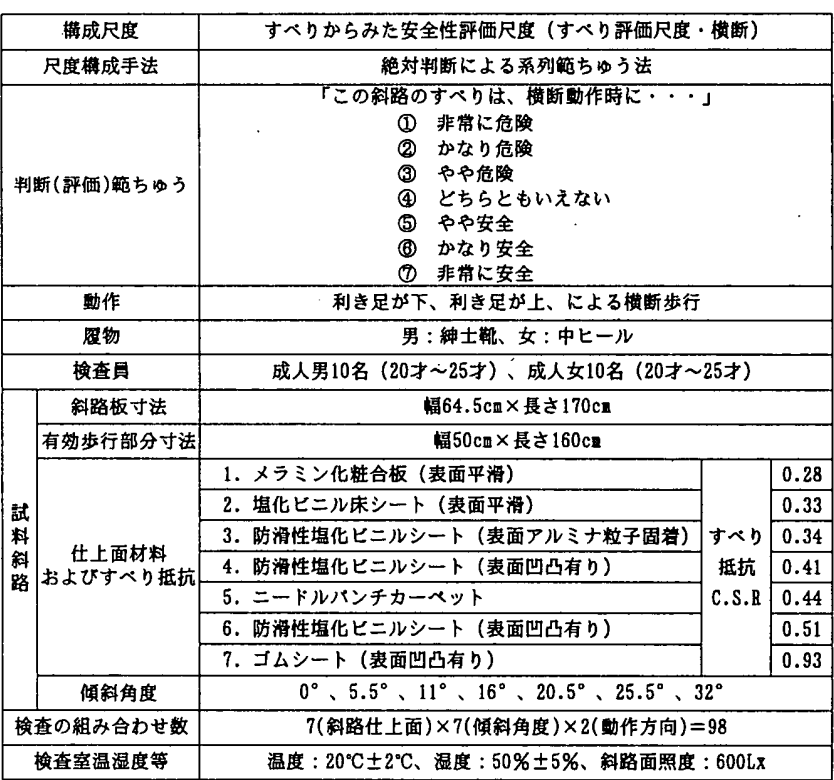




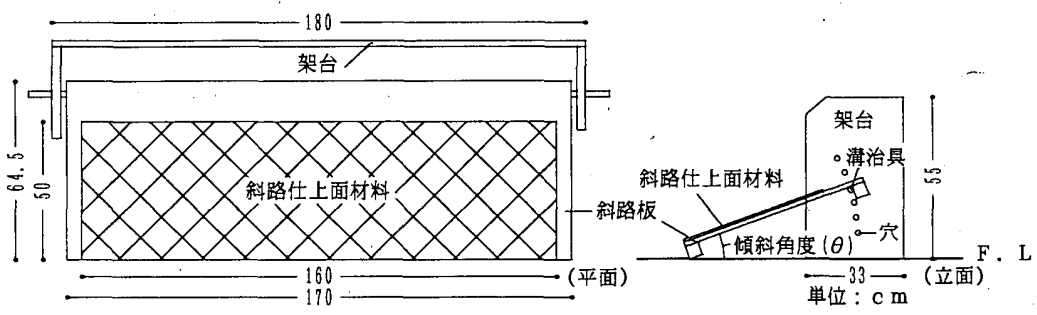

図 2 試料斜路の概要

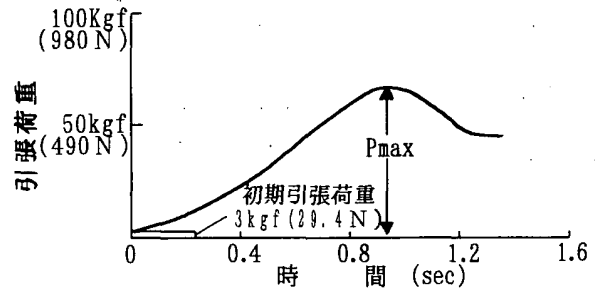

図 4 引張荷重・時間曲線の例

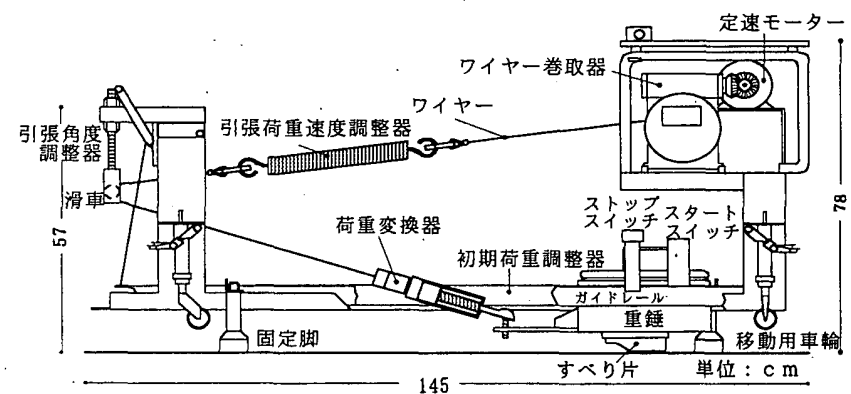

図 3 ・すべり試験機 $(0-Y \cdot P S M)$ の概要

\section{（ 3 ）動作の設定}

動作は試料斜路を 3 歩〜 4 歩で横断する歩行動作とした。ここで、 利き足の影響を考虑し、検查員ことに、利き足が斜路下側（谷）、 および斜路上側（山）の場合の判断をそれそれ求めることとした。 さらに、すべる試料でかつ傾斜角度が大きい場合、横断できない検 查員に対しては無理に横断せず片足を押しつける程度の動作で判 断してもよいこととした。

また、安全性に関する本研究の場合はより危険な状況で判断させ るのが重要なことから手摺は設置せず、安全性確保の観点からつね に検查者が検査員を介添することとした。

\section{（4）履物の選定}

屋内外で一般的に用いられる履物として、紳士靴、中ヒールを選 定した。なお足元の安全性が非常に悪くなるハイヒールは予備検查 の結果、特に傾斜角度の大きい場合すべりには関係なく動作できな いことが多かったため選定しないこととした。

また、履物底および試料斜路仕上面の性状を一定に保持し、つね に同じすべり抵抗を具現する観点から、検査室の温湿度環境を一定 にするとともに、写真 1 に示すようにC.S.R 測定時と同様に履物底 に綿ブロード（40 番）を随時貼布することとした。

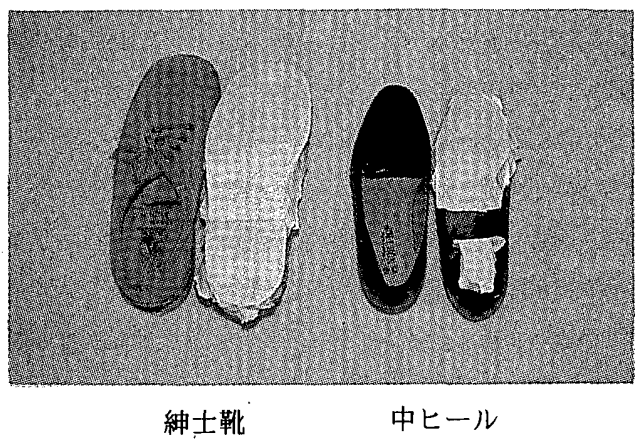

写真 1 履物

\section{（５）検查員の選定}

検查員としては、健常な成人男子 10 名と成人女子 10 名を選定 した。

なお、安全性の観点から最も重要な高齢者を代表とする身体的弱 者を検查員とすることを考えたが、本検查の条件下では健常な 60 才代の方でも動作自体行えない試料が多かったため、選定しないこ ととした。

\section{5.・1.2 検查の経過および結果}

5.1.19条件で検查を実施し、個々の刺激に対する判断範 ちゅうからなる基礎デー夕を得た。

検查状況を写真 2 に、検査の分散分析結果を表 2 に示す。

いずれの結果においても主効果が高度に有意であり寄与率も大 きいことから、試料斜路の刺激に有意な差があること、検查自体が 有効なことがわかる。また、個人差が有意な場合もあるが、寄与率 がいずれも主効果の寄与率と比較して非常に小さいことから判断 のほとんどは共通して試料斜路の刺激に依存した結果とみなせる。

すなわち、基礎データから構成される尺度は個人差をわずかに内 包するものの十分有効な尺度といえる。

なお、構成される尺度はすべり抵抗と傾斜をもとに判断した結果 から構成されると見做すべきであるが、総じてすべり評価尺度・横 断と呼び、かつ考察においてはすべりの評価と一元化して論ずるこ ととする。

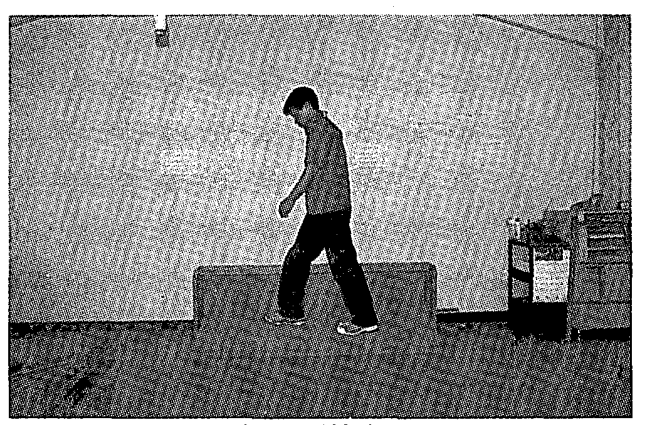

写真 2 検查状況

表 2 検査の分散分析結果

\begin{tabular}{|c|c|c|c|c|c|}
\hline \multirow{2}{*}{ 動作 } & \multirow{2}{*}{$\frac{\text { 検查貝 (履物) }}{\text { 項目 }}$} & \multicolumn{2}{|c|}{ 成人男（紳士靴） } & \multicolumn{2}{|c|}{ 成人女 (中ヒール) } \\
\hline & & 分散比 & 寄与率 $($ \% $)$ & 分散比 & 寄与率 (\%) \\
\hline \multirow{2}{*}{$\begin{array}{l}\text { 利 } \\
\text { 足横 } \\
\text { 足断 } \\
\text { 下 }\end{array}$} & 主効果 & $172^{* 4}$ & 93.9 & $320^{* 1}$ & 96.9 \\
\hline & 個人差 & $5^{* \prime}$ & 0.4 & 1 & 0.0 \\
\hline \multirow{2}{*}{$\begin{array}{l}\text { 利 } \\
\text { き.横 } \\
\text { 足·断 } \\
\text { 上 }\end{array}$} & 主効果 & $199^{\ddagger \ddagger}$ & 94.7 & $298^{* t}$ & 96.6 \\
\hline & 個人差 & $5^{* *}$ & 0.3 & 2 & 0.0 \\
\hline
\end{tabular}


5. 1.3 すべり評価尺度・横断の構成および考察

基礎デー夕を用い尺度構成理論 ${ }^{71}$ に従ってすべり評価尺度・横断 を構成した。図 5 に 4 刺激（傾斜角度 $7 \times$ 仕上面材料 $7=49$ ） の尺度值をそれそれの尺度線図上に示す。（図中、尺度値か近似す る場合は省略して表示している)

図から、性（履物）、利き足の上下、にかかわらず、試料斜路の

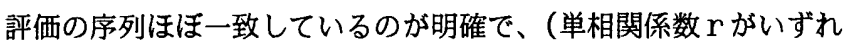
も 0.96 以上、 $r(47,0.01)=0.365)$ 代表的な一つ の方法によるすべり抵抗ですべての場合のすべり評価尺度・横断を 表示できる可能性を見出すことができる。

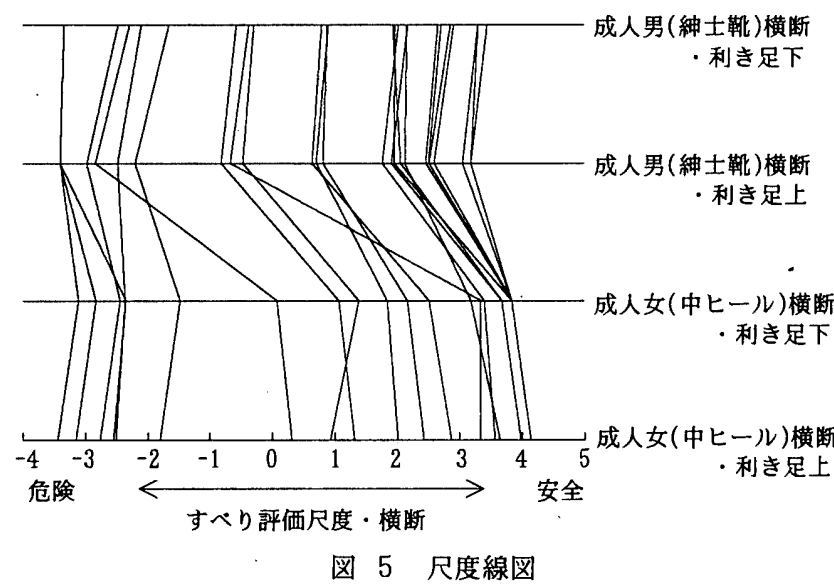

5.2. すべり評価尺度・横断を表示するすべり抵抗の設定

すべり抵抗を設定するに際し、まず、試料斜路仕上面材料のすべ り抵抗C.S.R との対応を検討した。

図6に両者の対応を示す。

図から、全体的にみると明確な対応が見られないが、いずれの場 合も傾斜角度ことにすべり評価尺度・横断と C.S.Rには明確な対応 が見られる。つまり、いずれの傾斜角度においてもC.S.R が大きく なると評価が安全側に移行すること、いずれのC.S.Rにおいても傾 斜角度が大きくなると評価か危険側に移行することがわかる。

以上の傾向は既往の成果 ${ }^{1}$ 、つまり成人の上り、下り、および方 向転換時の対応の傾向と同じことから、本研究においても、既往の 研究 ${ }^{1)}$ で傾斜角度を取り込んで一元的に斜路のすべりを表示でき るように設定し、高歯者の場合にも妥当性が検証された、2)すべり 抵抗C.S.R・L i (C.S.R- $\sin \theta)$ との対応を試みた。

図 7 に両者の対応を示す。

いずれの場合も C.S.R・L i とすべり評価尺度・横断はなめらかに 対応していることから、すべり評価尺度・横断を表示するすべり抵 抗としてC.S.R・L i を設定した。

ここで、C.S.R・L i はすべり抵抗が水平な場合と比較し、傾斜に より実効的に低下する他に、傾斜により足元が不安定になりより危 険となるなどの影響を一 $\sin \theta$ で補完している物理量と解釈するの が妥当と考える。

また、より以上の対応を示すすべり抵抗もあり得ると考えるが、 以降の検討において総括的に斜路のすべりを検討する際、既往の研 究1)、2)で設定したすべり抵抗と同一のすべり抵抗を設定するのが 好都合なことも、C.S.R・L i を設定した理由のひとつである。

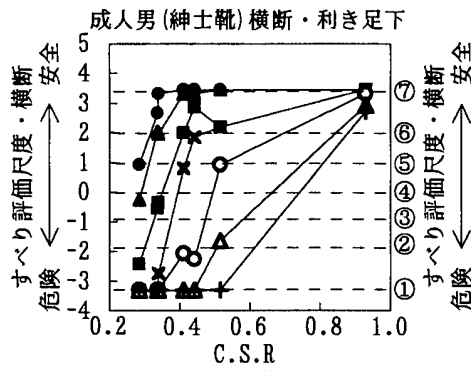

成人男 (紳士鞉) 横断・利き足上

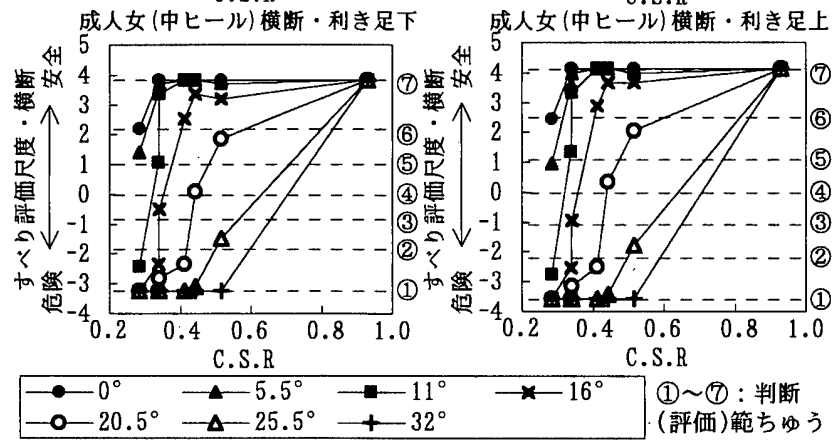

図 6 すべり評価尺度・横断とC.S.Rの対応
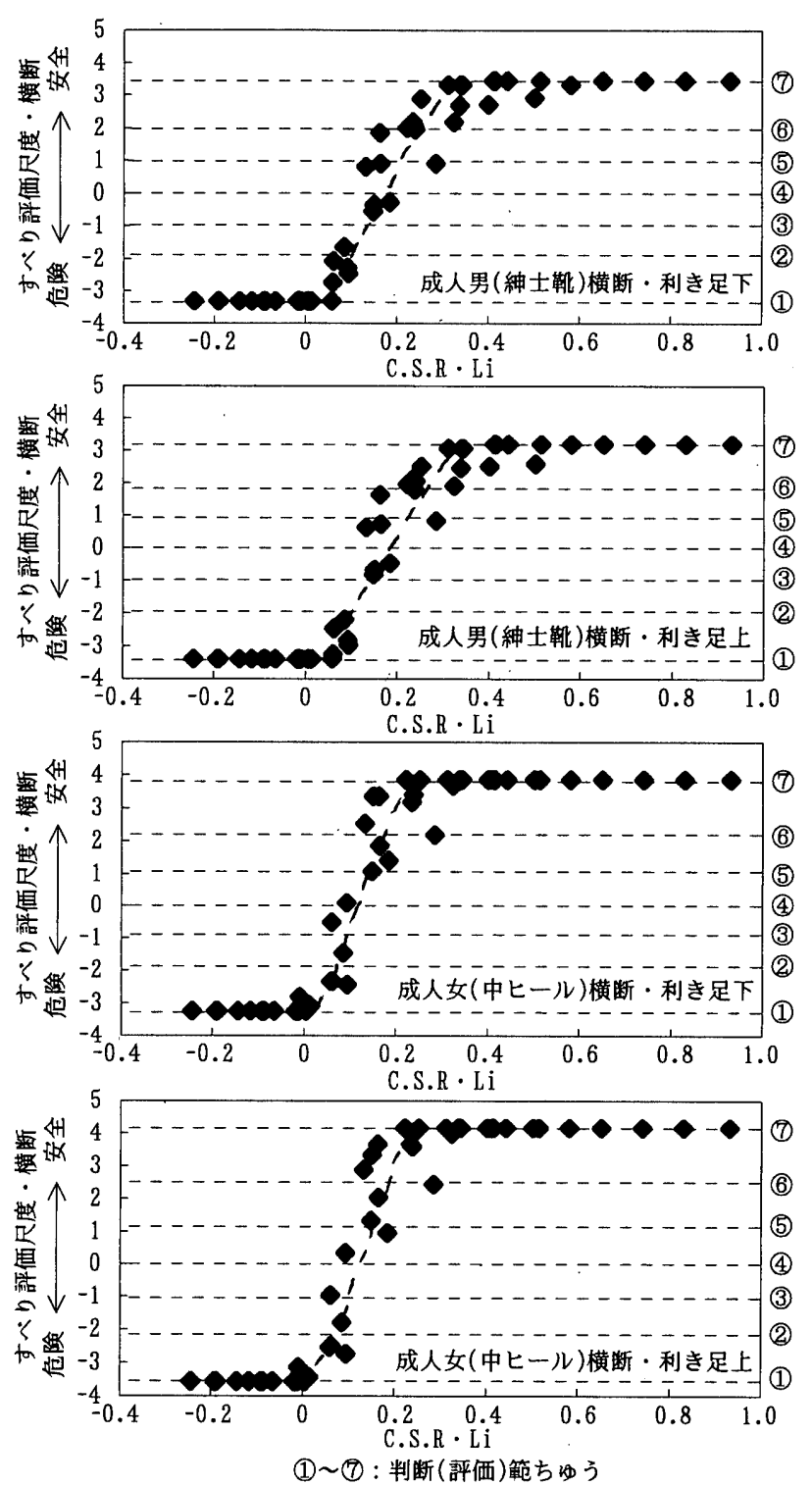

図 7 すべり評価尺度・横断とC.S.R・Li の対応 


\section{3. 横断時の安全性からみた斜路のすべりの評価指標の提示}

5.2.の検討結果から、図 7 を横断時の安全性からみた斜路の すべりの評価指標として提示する。

図で成人の上り、下りおよび方向転換さらには高跉者の下りの場 合 ${ }^{11 、 2)}$ と比較して特幑的なのは C.S.R・L i が一定值以下、あるい は一定值以上の範囲において、安全性の評価が、非常に危険あるい は非常に安全となる点にある。理由として、横断時の足の接触状況、 踏力の作用状況、姿勢などが他の動作時と異なることが想定される か、本論の範囲で明言することはできず、事実として認識するに留 める。

\section{6. 安全性からみた斜路のすべりの總括的評価指椤およひ評価方 法の提示}

既往の研究 ${ }^{11}$.2) と本研究において、人、履物、動作の組み合わ せことに安全性からみた斜路のすべりの評価指標（以降、個別評価 指標と呼ぶ）を提示した。

個別評価指標はすべて安全性からみたすべり評価尺度と C.S.R・L i の対応として提示しているが、対応の形態は図 8 に代表例として 示した2つに大別できる。

（イ）で特徵的なのはすべらないほど安全となる対応で、本研究で 図7に示した個別評価指標も含め、高齢者以外のすべての場合に該 当する ${ }^{1)}$ 。

(ロ)で特徵的なのはすべりに最適值がある対応で、高齢者の下り の場合に該当する ${ }^{2)}$ 。

ここですべりすきる場合は、(イ)、(ロ)共に危険であるが、すべ らなすきて危険となる(口)の場合は、つまずきによる転倒の危険性 などのためと考えられ、足腰が弱っている高齢者の下りの場合に顕 著であると解釈できる。
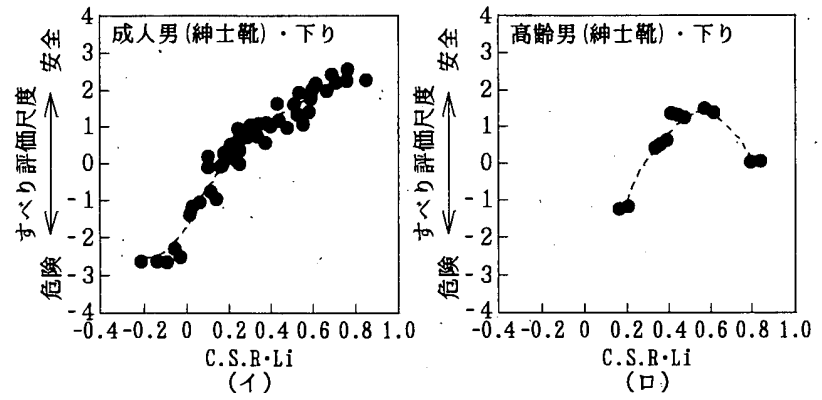

図 8 すべり評価尺度とC.S.R・Liの対応例 ${ }^{1)}$ 2)

以上の成果をもとに、安全性からみた斜路のすべりを総括的に評 価する評価指標を提示するが、まず本研究および既往の研究1)、2) で提示した個別評価指標に関して以下を前提とする。

（1）、検查員としては、健常な成人男子・女子、高齢の男子・女 子、体験装具を装着した健常な成人男子、を選定しており、安全性 からみて代表的な検査員を包含している。

（2）、動作としては、上り、下り、方向転換、横断を設定してお り、安全性からみて代表的な動作を包含している。

（3）、履物としては、紳土鞉、ハイヒ一ル、中ヒール、ローヒー ル、を選定しており、安全性からみて代表的な履物を包含している。 (4)、試料斜路のすべり抵抗および傾斜角度は害情を十分包含し
ている。

（5）、検查員、履物、動作に関しすべての組合せによる個別評価 指標が提示されていることが望ましいが、現実に検查が不可能なこ ともあったため、欠如している組合せがあるが大きな問題とはなら ない。

つきに、本研究で提示する総括的評価指標は、実際に用いられる ことを念頭においている。

それゆえ個別評価指標の検討の場合とは異なり、総括的評価指標 を提示する過程において危険側を含めて論ずることは混乱を招く 恐れがあると共に、安全性の確保の観点からは不必要なことから、 “どちらともいえない”の判断(評価)範ちゅ（以降、単に範ちゅ うと呼ふ）を下限の範ちゅうとして論を進めることとする。

以上を前提として、まず、図8(イ)に例示したC.S.R・L i に比例 して安全性が高くなる対応を示す個別評価指標について検討する。

これらの個別評価指標において、それそれれの範ちゅう(4)(どちら ともいえない)〜7(非常に安全)に該当するすべり評価尺度值と、 対応の中心傾向を示す曲線との交点の C.S.R・L i を求め図 9 に・印 で示した。ここで示したC.S.H・L i は人、履物、動作それぞれの条 件下における(4)〜 (7)各範ちゅうを具現する最小の C.S.R・L i、つま り許容すべり抵抗値となる。

さらに、斜路がいかなる人、履物、動作の条件下で使用に供され るかを特定できないため、すべての要因を包含した場合の許容すべ り抵抗值を提示する必要がある。

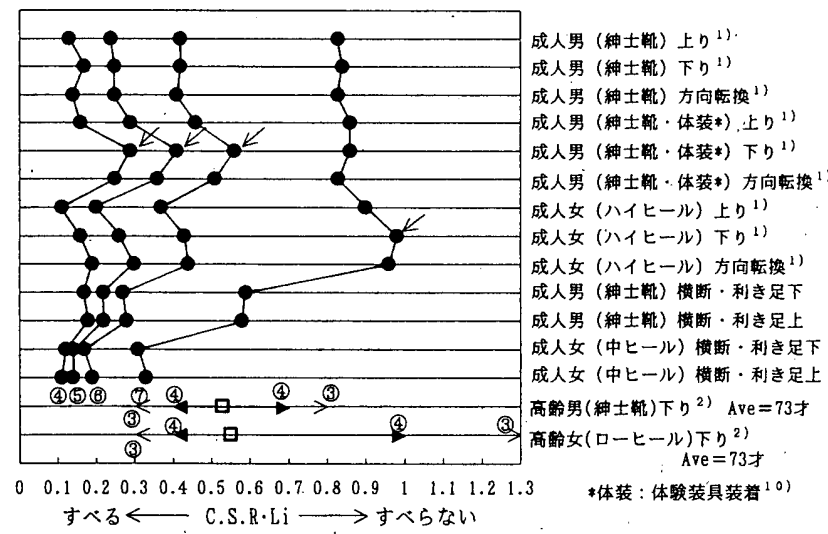

図 9 判断(評価)範ち听うとすべり抵抗値の関係

ここで図 9 において、すべての個別評価指標における(4)〜(7)各範 ちゅうの許容すべり抵抗値の最大值を、各範ちゅうを満足する許容 すべり抵抗值としてっと印のように提示できる。

さらに図 9 から、範ちゅう(4)〜(7)の許容すべり抵抗值を決定する 条件はすべて下りの場合でかつハイヒール、体験装具装着など、足 元が不安定になる条件下において決定されることがわかる。また、 本研究における横断の場合は、下りによって決定される許容值以上 の C.S.R・L i であれば(4)〜(7)いずれの範ちゅうの場合にも安全性を 確保できることもわかる。

つきに、図 $8(ロ) に$ 例示したC.S.R・L i に最適值がある対応を示 す個別評価指標について検討する。なお、個別評価指標はすべて高 齢者の場合でかつ、検查遂行の可否および検查効率の確保の観点か ら動作は下りとしさらに履物は男性が紳士靴、女性がローヒールに 
限定した場合の個別評価指標となっている ${ }^{2)}$ 。

ここで、評価指標は最適值が存在する評価尺度と C.S.R・L i との 対応となっているため成人の場合と異なり、各範ちゅうを具現する ひとつの許容すべり抵抗值を提示することは不可能であるが、

C.S.R・L i の最適值(口印)および各範ちゅうを満足する C.S.R・L i の範囲（せ：範ちゅう(4):やや安全、せ:範ちゅう(3):ど ちらともいえない）を図 9 の下段のように提示できる。

以上ふたつの提示をもとに、総括的に斜路のすべりの評価指標を 提示するとつきのようである。

斜路において、安全性の観点から最も重視すべき人の層は高齢者 を代表とする身体的弱者であるといえることから、図 9 より高齢者 の場合の最適值の範囲である C.S.R・L i = 0.53(男) 0.55 (女)を斜路のすべり抵抗の評価指標 (最適範囲)として提示できる。 ここで、提示した評価指標（最適範囲）は成人の場合、範ちゅう (7) (非常に安全) を具現する值とはならないか、範ちゅう(6)（かな り安全) を満足する範囲といえることから、大きな不都合はないと いえる。

一方、1 点の值に近い評価指標（最適範囲）をつねに具現するこ とは、さまさまな要因によりすべり抵抗が変動する実際においては 非常に困難といえる。それゆえ高齢者の場合の評価範ちゅう(4) (や や安全) (注) を具現するC.S.R・L i = 0.4〜0.7を許容範囲と.し斜 路のすべり抵抗の評価指標として提示する。

ここで、提示した許容範囲であれば成人の場合でも範ちゅう(5) (やや安全)を満足する評価指標となることから、大きな不都合は ないといえる。

なお、以上の考え方で提示した斜路のすべり抵抗の許容範囲 (C.S.R.L i=0.4〜0.7) は決定論的な值ではなく、ひとつの 考え方にもとづいた評価指標と想識すべきであり、できるたけ高齢 者の最適範囲を目標とすること、さらには本研究で提示した個別評 価指標を資料とし別の考え方ですべり抵抗の許容值あるいは許容 範囲を評価指標として設定すること、に異論はないことを付記する。

以上から、安全性からみた斜路のすべりの総括的評価方法を以下 のように提示する。

(1) 斜路上下方向のすべり抵抗 C.S.R を実際の条件下で求める。

ここで実際の条件下とは基本的に、以下を意味する。

使用する実際の履物底をすべり片とする。

表面介在物（水、泥、油など）を実際のものとする。

なお、JIS A 1454 では、代表的な履物底および表面介在物の仕 様を規定しているので、実際の条件に近似した一般的な状況を設定 するのに有用である。

（2）C.S.R と傾斜角度（ $\theta^{\circ} ）$ を用いた次式により斜路のすべ り抵抗 C.S.R・L i を求める。

C.S.R.L $\mathrm{i}=$ C.S.R $-\sin \theta^{\circ}$

（3）C.S.R・L i を下記の評価指標に照合して安全性を評価する。 最適範囲 : C.S.R.L i : $0.53 \sim 0.55$

許容範囲 : C.S.R・L i : $0.4 \sim 0.7$

なお、人、履物、動作を特定できる場合は、これまで提示した個 別評価指標あるいは図 9 を用いて評価しても問題ないことを付記 する。

\section{7. 結}

横断時の斜路のすべりの検討結果と、著者らによる既往の研究成 果 ${ }^{1) 、 2)}$ を総合して、総括的に斜路のすべりを評価する方法を提示 した。

結びにあたり、危険な検查に参加していたたいた検查員の皆様、 斜路仕上面に用いる材料を提供いただいたメ一カー各位に感謝し ます。

なお、本研究における検査は平成 13 年度東北工業大学工学部建 築学科小野研究室研修生、小畑貴嗣君、佐々木芳尚君が担当したこ とを付記します。

（注）検查において、成人の場合はすべて表 1 に示すように 7 段階の判 断範ちゅうを用いているが、高秢者の場合は、判断のし易さの観点から 5 段階としており、(5)(非常に安全)の次の範ちゅうは(4)(やや安全)(3)(ど ちらともいえない)としている2゙。

\section{〔参考文献〕}

1）小野英哲、北山大、高橋宏樹：安全性加らみた斜路のすべりの評価方 法に関する研究、日本建築学会構造系諭文集 448 号, pp.11 18、1993.6

2）小野英哲、高橋宏樹、泉誶太、高橋成明 : 高齢者の安全性からみた床 および斜路のすべりの評価方法の提示、日本建策学会構造系詅文集、 484 号、pp.21 29、1996.6

3）宇野英隆、直井英雄、遠藤佳宏 : 床の状態がすべりに及ほす影暨につ いて、日本建築学会大会学術講演梗概集、pp.615 616、1973.10

4）田山茂夫、坂田種男: 斜路の安全性に関する研究、日本建築学会大会 学術講演梗概集、pp.859 860、1981.9

5) DIN 51097 "Bestimmung der rutschhemmenden Eigenschaft"

6）小野英哲、井戸川純子、高橋宏樹：車椅子の走行性加らみた床、舗装 路、斜路の相対的評価方法に関する研究 一すべりの锶点からー、日 本建築学会諭文報告集、528 号 pp33 38、2000.2

7） J.P.ギルホート、秋重義治監訳：精神測定法、培風館、1964

8）小野英哲：休のすべりおよびその評価方法に関する研究、その2、す ベり試験機の設計・試作のための基礎的資料の集積およびすべり試験 機の基本構想、日本建築学会論文報告集、第 333 号、pp.1 7、1983.11

9）小野英哲、河田秋澄、宮木宗和、川村清志、小西敏正、三上貫正、橋 田浩、吉岡丹:床のすべりおよびその訮価方法に関する研究、その $3 、$ すべり試験機の設計·試作、日本建策学会論文報告集、第 346 号、pp.1 $\sim 8 、 1984.12$

10）川村次郎、瑇淵隆司、後藤義明：健常者がからたの不自由を体験する 装具（体験装具)、第 7 回日本義肢装具学会学術大会、フロロクラム抄 録集、1991.3 